\title{
AGAMA, SAINS, DAN COVID-19: PERSPEKTIF SOSIAL-AGAMA
}

\author{
$\frac{\text { M. Alkaf }}{\text { Universitas Muhammadiyah Yogyakarta }}$ \\ alkaf.muchtar@gmail.com
}

\section{Abstrak}

Studi ini mengkaji hubungan agama, sains, dan Covid-19 dalam perspektif sosial-agama. Ada tiga pertanyaan utama dalam studi ini: (a) bagaimana titik perjumpaan dan pertengkaran antara agama dan sains itu berlangsung; (b) bagaimana respons dan perspektif agama terhadap wabah; dan (c) bagaimana kemampuan agama bertahan di tengah ancaman pandemi Covid-19. Studi menemukan bahwa selalu ada titik tengkar dan dialog antara sains dan agama. Lalu, doktrin agama juga memiliki pandangan bahwa wabah itu bisa jadi hukuman atau cobaan dari Tuhan sehingga menjadi anti sains, walau ada organisasi Muhammadiyah yang akrab dengan sains sehingga ikut memengaruhi landasan pemikiran keagamaan yang dibangunnya. Terakhir, agama diyakini dapat bertahan karena modal institusi dan tradisi spritualitas di tengah kuatnya Covid-19.

Kata kunci: Agama, Covid-19, Sains, Spritualitas

\section{Pendahuluan}

Apa yang terjadi akhir-akhir ini setelah munculnya pandemi Covid-19 memengaruhi banyak hal dalam segala lini kehidupan manusia. Tentu saja, yang menjadi tantangan beratnya adalah ketika pandemi ini menimbulkan banyak korban di seluruh dunia. Catatan resmi dari WHO, yang positif terpapar virus itu mencapai 4.013.728, dengan kematian mencapai angka 278. 993 jiwa. ${ }^{189}$ Sedangkan di Indonesia, per 11 Mei 2020, catatan angka dari Covid-19 sudah menyentuh angka 14.265 yang positif, 2.881 yang sembuh dan 991 yang 
meninggal. ${ }^{190}$ Hal itu kemudian berimplikasi dalam segala relasi, ekonomi, politik, budaya dan agama. Dalam hal ini, agama mendapatkan tantangannya ketika pandemi semakin meluas. Agama lalu dipertanyakan relevansinya dalam kehidupan manusia. ${ }^{191}$ Perdebatan yang mempertanyakan relevansi agama, kemudian juga dihubungkan dengan posisinya yang berhadap-hadapan dengan sains, bukanlah topik baru. Kajian dilakukan oleh Yuval Noah Harari, yang melihat hubungan agama - terutama agama besar - dan manusia dalam sejarah panjang dunia. Agama, dalam pendefinisian Harari, sebagai penyatuan dari manusia-manusia yang ada di bumi, baginya agama demikian sama seperti keberadaan kerajaan besar dan mata uang, keduanya juga mengikat umat manusia. ${ }^{192}$ Lalu, lebih dari itu, di bagian yang lain, Harari melihat pencapaian manusia dengan optimisme yang besar, dengan apa yang disebutnya sebagai transformasi manusia dari homo sapiens ke homo deus, dari manusia menjadi tuhan. ${ }^{193}$

Sejauh ini, literatur, terutama diskursus di Indonesia yang membicarakan hubungan agama dan sains pada integrasi keduanya. Sebab pada awalnya terlihat dapat saling berbenturan, sehingga perlu dicari rumusan untuk mempertemukan antara keduanya. ${ }^{194}$ Di antaranya melalui diskursus ayatayat sains yang terkandung dalam Al-Quran. ${ }^{195}$ Kementerian Agama tak luput daripadanya. ${ }^{196}$ Pembicaraan tentang integrasi sains dan agama juga sudah menjadi wacana yang masif di beberapa perguruan tinggi Islam. ${ }^{197}$ Pembicaraan

190. https://covid19.go.id. Diakses tanggal 12 Mei 2020.

191. Salah satu puisi yang sempat viral di awal munculnya Covid-19 ditulis oleh Said Muniruddin. Dalam puisinya, yang sarat dengan makna sufistik, dia menulis tentang runtuh ritual agama, dan menawarkan pendekatan sufisme untuk meletakkan ulang makna keberagamaan yang menyentuh nilai ketuhanan. Berikut puisinya, Bubarnya Agama/ Makkah sepi// Madinah sunyi// Kakbah dipagari// Masjid tutup// Jamaah bubar// Jumat batal// Umrah di stop// Haji tak pasti// Lafadz adzan berubah// Salaman dihindari// Corona datang// Seolah-olah membawa pesan// Ritual itu rapuh!// Ketika Corona dating// Engkau dipaksa mencari Tuhan// Bukan di tembok Kakbah// Bukan di dalam Masjid//

Bukan di mimbar khutbah//Bukan dalam thawaf// Bukan pada panggilan azan// Bukan dalam shalat jamaah// Bukan dengan jabat tangan// Melainkan pada keterisolasianmu// Pada mulutmu yang terkunci// Pada hakikat yang tersembunyi// Corona mengajarimu,//Tuhan itu bukan (melulu) pada keramaian// Tuhan itu bukan (melulu) pada syariat// Tuhan itu ada pada jalan keterputusanmu// Dengan dunia yang berpenyakit// Corona memurnikan agama//Bahwa tak ada yang boleh tersisa// Kecuali Tuhan itu sendiri!// Temukan Dia. https://saidmuniruddin.com/2020/03/16/bubarnya-agama/ Diakses tanggal 11 Mei 2020.

192. Yuvah Noah Harari, Sapiens: A Brief History of Humankind (Canada: Signal Book, 2014), hlm. 183.

193. Yuvah Noah Harari, Homo Deus: A Brief History of Tomorrow (HarperCollins, ), hlm. 19.

194. Bambang Sugiharto, Ilmu dan Agama dalam Kurikulum Perguruan Tinggi dalam Zainal Abidin Bagir dkk. (Editor), Integrasi Ilmu dan Agama: Interpretasi dan Aksi, (Bandung: Mizan, 2005), hlm. 39.

195. Septiana Purwaningrum, Elaborasi Ayat-Ayat Sains dalam Al-Quran: Langkah Menuju Integrasi Agama dan Sains dalam Pendidikan, (Kediri: Inovatif: Jurnal Penelitian Pendidikan, Agama dan Kebudayaan, 2015), hal. 124.

196. Faizin, Integrasi Agama dan Sains dalam Tafsir Ilmi Kementerian Agama RI, (Riau: Jurnal Ushuluddin, 2018), hal. 19.

197. Abu Darda, Integrasi Ilmu dan Agama: Perkembangan Konseptual di Indonesia, (Ponorogo: At-Ta'dib, 2015), hlm. 45. 
ini bertujuan untuk saling mempertemukan berbagai disiplin ilmu guna memahami kompleksitas persoalan sekaligus memberi jalan penyelesaian. ${ }^{198}$ Selain itu, pelacakan literatur untuk melihat posisi agama dalam perspektif sosial-agama, dapat dilihat dari bagaimana posisi agama sebagai bagian penting dari struktur sosial, sumber nilai dalam pembentukan tatanan masyarakat dan kebutuhan batin individu. ${ }^{199}$ Agama itu sendiri sebuah institusi, yang diorganisir berdasarkan fungsinya, komunal, institusional dan asosiasonal. ${ }^{200}$ Berger memberikan pemaknaan terhadap agama sebagai hasil konstruksi realitas sosial yang dilakukan oleh manusia yang kemudian menciptakan pranata sosial. ${ }^{201}$ Lalu, seperti kata Weber, agama mengkonstruk perihal yang sakral dan kemudian menjaganya dengan penekanan kepada keharusaan taat kepada norma-norma yang telah disusun. ${ }^{202}$ Secara lebih khusus, diskursus mengenai posisi Islam dengan manusia, selalu menjadi problematik, ketika agama ini diberikan penafsiran, karena variatifnya ruang tafsir dalam tradisi intelektual Islam. Oleh karenanya, dalam konsteks sosial kemasyarakatan, Islam dipandang sebagai agama yang memiliki dua medium, privat dan publik, atau disebut juga individu dan sosial. Dalam hal itu pula Islam dipandang sebagai agama yang memiliki orientasi kesalehan sosial untuk memastikan adanya transformasi sosial untuk kemanusiaan. ${ }^{203}$ Transformasi demikian dapat dikatakan sebagai upaya menemukan agama untuk menegakkan tatanan sosial, atau apa yang disebut dengan Islam Transformatif. ${ }^{204}$ Bahkan, upaya menggerakkan agama juga dapat dilihat dari peranan tasawuf sebagai bagian dari misi kemanusiaan yang merupakan bagian dari ajaran Islam. ${ }^{205}$

Tujuan tulisan ini untuk melengkapi pembicaraan antara agama, wabah dalam hal ini Covid-19 - dalam perspektif sosial keagamaan. Di mana banyak riset sebelumnya yang disinggung baru membicarakan integrasi antara agama dan sains serta posisi agama dalam kehidupan sosial, namun belum menyentuh pembicaraan mengenai hubungan antara agama, sains, dan Covid-19. Hal

198. Andik Wahyun Muqoyyidin, Integrasi dan Interkoneksitas IImu-IImu Agama dan Sains Menuju Pendidikan Tinggi Islam Center of Execellences, (Bandung: EduSentris, 2014), hlm. 170.

199. Syaiful Hamali, Agama dalam Perspektif Sosiologis, (Lampung: Al-Adyan, 2017), hlm. 223-224.

200. Mun'im Sirry, Membendung Militansi Agama: Iman dan Politik dalam Masyarakat Modern, (Jakarta: Erlangga, 2003), h/m. 24.

201. Ali Machsan Moesa, Nasionalisme Kyai: Konstruksi Sosial Berbasis Agama, (Yogyakarta: LKiS, 2007), hlm. 70.

202. Max Weber, Sosiologi Agama, (Yogyakarta: IRCiSoD, 2019), hIm. 407.

203. Ahmad Baso, Alquran dan Transformasi Sosial dalam Syeh Mahdi dan Singgih Agung, Islam Pribumi: Mendialogkan Agama, Membaca Realitas, (Jakarta: Erlangga, 2003), hlm. 11-12.

204. Moeslim Abdurrahman, Islam sebagai Kritik Sosial, (Jakarta: Erlangga, 2003), hlm. vi.

205. Said Aqil Siraj, Tasawuf sebagai Kritik Sosial: Mengedepankan Islam sebagai Inspirasi, Bukan Aspriasi, (Bandung: Mizan, 2006), hlm. 16. 
ini dikarenakan Covid-19 merupakan wabah baru. Sejalan dengan itu, dapat dirumuskan tiga pertanyaan tentangnya: (a) bagaimana titik perjumpaan dan pertengkaran antara agama dan sains;. (b) bagaimana respons dan perspektif agama terhadap wabah; dan (c) bagaimana kemampuan agama bertahan di tengah ancaman pandemi Covid-19.

Tulisan ini didasarkan pada tiga argumen: (a) Titik perjumpaan dan pertengkaran antara agama dan sains didasarkan pada basis ontologi dan epistemologi dari keduanya. Bagi Islam, sains bukanlah hal yang terpisah dari ajaran agama, bahkan diyakini sebagai bagian dari upaya memperkuat kebenaran dalil dan doktrin agama; (b) Agama memiliki dua cara dalam memberikan respons, pertama dilihat sebagai bagian dari doktrin agama, apakah itu cobaan atau hukuman, sebagaimana yang sering dibaca dalam kitab-kitab suci. Sedangkan dalam menawarkan perspektifnya, agama menjadikan basis komunal, seperti ulama, institusi dan tafsir sebagai cara menghadapi wabah; (c) Agama tidak akan meninggalkan ritual dan basis komunalnya, walau di awal wabah sempat mendapat kritikan tajam dari penganut sufisme yang mempercayai bahwa spritualitas akan mengatasi ritual dan formalisme agama. Peranan ulama, instansi keagamaan, ruang publik keagamaan dan produksi tafsir agama atas wabah akan semakin mendapatkan perannya.

\section{Titik Perjumpaan dan Pertengkaran antara Agama dan Sains}

Titik awal dari agama adalah kepercayaan terhadap hal yang abstrak, yang disebut iman, dalam pengertian bahwa kebenaran yang dikandungnya berasal dari Tuhan dan bukan merupakan rekayasa dari manusia tentang keberadaan kekuatan adikodrati. ${ }^{206}$ Kepercayaan dalam agama tidak bisa dibuktikan secara empirik, ${ }^{207}$ sehingga penganut agama harus meyakini hal tersebut tanpa perlu mempertanyakan apakah hal demikian benar atau tidak. Sains sebaliknya, dengan mengutip Arthur J. D’Adamo yang mengatakan bahwa sains dibangun atas pengertian baru kemudian pada keyakinan. ${ }^{208}$ Pada titik inilah, sains berbeda jalan dengan agama, ${ }^{209}$ disebabkan oleh basis epistemologi yang berbeda. ${ }^{210}$

206. Amri Marzali, Agama dan Kebudayaan (Bandung: Umbara, 2016), hIm. 5.

207. Zuhari Misrawi, Al-Quran Kitab Toleransi: Tafsir Tematik Islam Rahmatan Lil 'Alamin, (Jakarta: Pustaka Oasis, 2010), hlm. xxviii

208. Kata Pengantar Budhy Munawar-Rachman dalam Komaruddin Hidayat dan Muhammad Wahyuni Nafis, Agama Masa Depan: Perspektif Filsafat Perennial, (Jakarta: Gramedia, 2003), hlm. 16.

209. Pada perdebatan lainnya, mengenai terlepasnya sains diri dari filsafat, sehingga kehilangan dimensi religiusitas dan transendentalisme sehingga berakibat sains kemudian menghantam nilai-nilai kemanusiaan, lihat Haidar Bagir, Buku Saku Filsafat Islam, (Bandung: Mizan, 2005), hlm. 51-53.

210. Tawarannya adalah dengan beranjak melihat darimana basis sainsnya dibangun, apakah dari hikmah atau filsafat. Lihat Idrus Shahab, Beragama dengan Akal Jernih, (Jakarta: Serambi, 2007), hlm. 198-199. 
Dalam sejarah pertengkaran itu, tentu saja mengenai teori evolusi yang berkembang dalam perdebatan antara saintis di Barat dengan kaum agamawan $^{211}$. Penemuan ilmiah Charles Darwin kemudian menjadi perdebatan panjang dengan doktrin di dalam Bible mengenai kitab Kejadian. ${ }^{212}$ Hal lain juga berkembang pada penemuan ilmiah tentang orientasi seksual dan identitas gender, yang kemudian berhadap-hadapan dengan doktrin agama bahwa orientasi seksual hanya satu yang direstui oleh Tuhan, yakni antara laki-laki dengan perempuan. ${ }^{213}$ Norma-norma agama ini kemudian menjadi titik tengkar sengit ketika para agamawan yang meosisikan diri menjadi juru bicara Tuhan, ${ }^{214}$ dengan para penentangnya, seperti saintis dan kaum humanis yang berpegang kepada antroposentris.

Keadaan ini kemudian berakibat pada dua titik ekstrim, agama yang menolaksains karena dianggap penemuan sains malah menjauhkan manusia dari keyakinan kepada hal gaib, seperti Tuhan, dan otomatis hal itu akan memperngaruhi tingkat loyalitas kepada agamawan sebagai institusi keagamaan. ${ }^{215}$ Sedangkan kutub berikutnya, sains terus tumbuh dengan semakin otonom sehingga akan berakhir pada ateisme, ${ }^{216}$ agnostik atau sekularisme. Segala hal yang awalnya diterangkan oleh agama secara abstrak dan yang mendengarnya harus meyakini tanpa syarat, lalu dengan adanya penemuan sains, hal-hal demikian terbantahkan. Tentu saja, hal yang paling dikenang dalam perdebatan antara sains dan agama adalah tentang bumi itu datar atau bulat. Dalam kitab suci, baik Islam maupun Kristen, secara tekstual disebut bahwa bumi datar dan dihamparkan, namun penemuan

211. Syarif Hidayatullah, Agama dan Sains: Sebuah Kajian tentang Relasi dan Metodologi, (Yogyakarta: Jurnal Filsafat, 2019), hlm. 117.

212. Fritz Ridenour, Dapatkah Alkitab Dipercaya?, (Jakarta: Gunung Mulia, 2000), hlm. 135-37.

213. Beberapa kajian di Indonesia, sedari awal sudah menempatkan orientasi seksual LGBT sebagai perilaku menyimpang, lihat Yudianto, Fenomena Lesbian, Gay, Biseksual dan Transgender (LGBT) di Indonsia serta Upaya Pencegahannya, (Lampung: Nizham, 2016), hlm. 62. LGBT juga dianggap bertentangan dengan perspektif Islam, lihat Tri Ermayani, LGBT dalam Perspektif Islam, (Semarang: Humanika, 2017), hlm. 147. Selain itu, LGBT juga ditimbang dalam kajian HAM dan agama dalam ruang lingkup perundang-undangan Indonesia, lihat Roby Yansyah dan Rahayu, Globalisasi Lesbian, Gay, Biseksual, dan Transgender (LGBT): Perspektif HAM dan Agama dalam Lingkup Hukum di Indonesia, (Semarang: Law Reform, 2018), hlm. 132. Kemudian, isu LGBT juga menjadi fokus di media surat kabar dengan framing anti LGBT, lihat Suranto Aw, Dyna Herlina dan Benni Setiawan, Agama dan Media Diskursus LGBT dalam Opini SKH Republika, (Surakarta: Komuniti, 2017) hlm. 105.

214. Siapa yang menjadi juru bicara Tuhan selalu menjadi problematika. Hal ini berkaitan dengan siapa yang paling otoritatif menafsikan maksud suara Tuhan. Mengenai topik ini, Khaled Abou Fadl menulis tentang perbedaan siapa yang akan bersuara otoriter dan siapa juga yang disebut memiliki otoritatif, lihat Khaled M. Abou Fadl, Atas Nama Tuhan: dari Fiqh Otoriter ke Fiqh Otoritatif, (Jakarta: Serambi, 2004). Pendekatan lain dalam membaca maksud Tuhan, dengan memakai perspektif hermeneutika, lihat Komaruddin Hidayat, Menafsirkan Kehendak Tuhan, (Jakarta: Teraju, 2004).

215. Pada kasus berbeda, penolakan terhadap agama, tidak lagi menjadi monopoli kaum Kristen di Barat, melainkan juga sudah merambah dunia muslim, seperti di Saudi Arabia, sebuah wilayah yang sangat kental dengan Islam skriptualisnya, lihat Hannah Wallance, https://secularhumanism.org/2020/01/menwithout-god-the-rise-of-atheism-in-saudi-arabia/. Diakses tanggal 17 Mei 2020.

216. Tony Ilham Prayogo dan Hadi Fathurizka, Ateisme dalam Perspektif Barat dan Timur, (Ponorogo: Kalimah, 2019), hlm 101-102. 
ilmiah mengatakan sebaliknya. Penemuan sains yang terus berlanjut sampai saat ini, seperti mengurangi makna keberagamaan atau otoritas keagamaan. Agamawan lalu mendapatkan ancaman terhadap otoritasnya, misalnya pada kasus terbaru dengan berkembangnya dunia digital, umat beragama memiliki rasa otonom untuk memilih sendiri apa yang hendak didengarnya. ${ }^{217}$

Titik tengkar ini, antara agama dan sains dapat dilihat sebagai bias sejarah modern Barat. Sedangkan pemikir Islam seperti Al Attas ${ }^{218}$ dan Ismail Al Faruqii $^{219}$ meyakini bahwa dalam Islam, agama dan sains dapat melakukan perjumpaan yang bahkan disebutnya dengan Islamisasi pengetahuan. ${ }^{220}$ Islamisasi ini tidak kebal kritik, baik karena warna apologetiknya maupun bangunan keilmuannya. ${ }^{221}$

Namun, cita-cita dari pemikir yang meyakini bahwa adanya islamisasi ilmu karena melihat sains yang berkembang di Barat malah menjauhkan manusia dari makna kemanusiaannya. Sains yang tercerabut dari makna ilahiah yang kemudian melahirkan bencana kemanusiaan, ${ }^{222}$ terutama menyebabkan perubahan iklim. ${ }^{223}$ Kelompok Islamisasi atau integrasi keilmuan ini meyakini kalau agama dan sains dipertemukan, maka akan dapat menjawab persoalan kemanusiaan secara lebih komprehensif. Di Indonesia, ide tentang islamisasi dikembangkan dengan kuat oleh murid-murid Naquib Al-Attas yang berbasis di lembaga INSIST. 224 Sedangkan di sisi lain, upaya menjembatani antara agama dan sains, diperlihatkan pada semangat pembentukan UIN di seluruh pelosok Indonesia. Dan yang paling elaboratif terhadap isu itu, yang disebut sebagai

217. Shafrida Wati, M. Alkaf dan Zahratul Idami, Agama Generasi Milineal: Fenomena Hijrah dan Perubahan Landscape Keislaman di Aceh (Langsa: Penelitian IAIN Langsa, 2019). Tidak diterbitkan.

218. Pemikir dari Malaysia ini mendirikan International Institute of Islamic Thought and Civilisation (ISTAC) yang menjadi tempat persemaian gagasan Islamisasi Pengetahuan.

219. Pemikir kelahiran Palestina ini pindah ke Amerika Serikat, lalu mendirikan The International Institute of Islamic Thougth. Biografi singkatnya dapat dibaca di https://iiit.org/en/dr-ismail-al-faruqi/.

220. Siti Yumnah, Diskursus Islamisasi Pengetahuan, (Bangil: Pancawahana, 2019), hlm. 44.

221. Ziauddin Sardar adalah pemikir yang paling keras melakukan kritik terhadap konsep Islamisasi Pengetahuan. Lihat Muslih, Kritik Ziauddin Sardar terhadap Konsep Islamisasi Ilmu Pengetahuan Ismail Al-Faruqi (Yogyakarta: Tesis UIN Sunan Kalijaga, 2017). Tidak diterbitkan. Lihat Muhammad Taufiq dan Muhammad Yasir, Mengkritisi Konsep Islamisasi IImu Ismail Raji Al Faruqi, (Yogyakarta: Jurnal Ushuluddin 2017), hlm. 108-109.

222. Ahmad Zainul Hamdi, Agama di Tengah Jaring-jaring Dunia Modern, (Surabaya: Religio, 2013), hlm. 1.

223. Fachruddin M. Mangunjaya, Bertahan di Bumi: Gaya Hidup Menghadapi Perubahan Iklim, (Jakarta: Yayasan Obor Indonesia, 2008).

224. Lembaga ini aktif menerbitkan pikiran-pikiran di jurnal Islamia, mengenai ide Islamisasi pengetahuan, Islamic Wordview dan kritik terhadap, apa yang disebut liberalisme, pluralisme dan sekularisme. Bahkan Lembaga ini secara khusus pernah mengadakan kursus pemikiran Syed Naquib Al-Attas, https://insists.id/ pengantar-pemikiran-syed-muhammad-naquib-al-attas/. Diakses 17 Mei 2020. 
integrasi dan interkoneksi ilmu pengetahuan, seperti yang dilakukan di UIN Sunan Kalijaga Yogyakarta melalui pemikir utamanya, M. Amin Abdullah. ${ }^{225}$

\section{Respons dan Perspektif Agama terhadap Wabah}

Untuk menjawab bagian ini, apa yang terjadi di Aceh dapat dijadikan sebagai studi kasus. Ketika Covid-19 menyerang, wabah dilihat dalam kacamata kearifan orang terdahulu, sehingga mendorong muncul gerakan mengarak obor di sepanjang kampung. ${ }^{226}$ Arakan obor dipercayai dapat mengusir Covid-19 sebagaimana pada masa lalu, ketika nenek moyang mereka berhasil mengusir wabah dengan obor dan bacaan dari al-Quran. Di Aceh, Covid-19 dilihat sebagai kelanjutan wabah-wabah yang pernah ada di masa nenek moyang, sehingga ketika menghadapi wabah itu, ${ }^{227}$ logika yang digunakan seperti yang disampaikan para ahli budaya dari Aceh dengan melihat masa lalu sebagai cara menghadapi Covid-19. ${ }^{228}$ Seperti ada keyakinan bahwa virus itu akan dapat ditangkal ketika jari secara berselang ditempel daun inai. ${ }^{229}$ Sikap anti sains itu diamini oleh para ulama di Aceh bahwa dengan tetap menjalankan ajaran agama, sehingga selama bulan Ramadan 2020, tidak ada masjid yang ditutup, 230 walau MUI dan Kementerian Agama telah mengeluarkan himbauan agar tempat-tempat ibadah dikosongkan dari keramaian. ${ }^{231}$

Pertanyaannya, bagaimana sebenarnya agama, atau agamawan memberikan perspektifnya terhadap wabah. Dalam agama, diyakini kalau Tuhan itu marah kalau ajarannya tidak diikuti. ${ }^{232}$ Kemarahannya itu ditampilkan dengan diberikan azab kepada umat manusia yang membangkang. Cerita pembangkangan dan azab yang diterima itu banyak diceritakan dalam agama-agama Abrahamik,

225. M. Amin Abdullah dkk, Islamic Studies dalam Paradigma Integrasi Interkoneksi: Sebuah Antologi, (Yogyakarta: Suka Press, 2007).

226. https://bagbudig.com/pandemi-corona-dan-suwa-empire/. Diakses 17 Mei 2020.

227. https://aceh.tribunnews.com/2020/03/23/virus-dan-obat-penangkalnya-dalam-perspektif-masyarakataceh. Diakses tanggal 17 Mei 2020.

228. https://www.tagar.id/daya-tahan-tubuh-orang-aceh-kuat-di-tengah-corona. Diakses tanggal 17 Mei 2020.

229. https://aceh.tribunnews.com/2020/04/02/memerahkan-jari-dengan-daun-inai-dipercaya-bisa-cegahcorona-benarkah. Diaskes 17 Mei 2020.

230. https://aceh.tribunnews.com/2020/04/21/mpu-aceh-bolehkan-warga-shalat-tarawih-di-masjid-asalterpenuhi-syarat-ini. Diakses tanggal 17 Mei 2020.

231. https://kemenag.go.id/berita/read/513202/dirjen-bimas-islam--ramadan-di-rumah-tak-mengurangikualitas-ibadah. Diakses tanggal 17 Mei 2020. Lihat https://kemenag.go.id/berita/read/513332/menag-masih-pandemi--salat-id-di-rumah-dengan-keluarga-inti. Diakses tanggal 17 Mei 2020. Lihat https://mui. or.id/berita/27848/mui-keluarkan-tausiyah-ramadhan-1441-h-di-tengah-wabah-covid-19/. Diakses tanggal 22 Mei 2020

232. Keberagamaan demikian, yang diprotes oleh Ahmad Wahib dalam catatan hariannya. Lihat ulasan itu dalam https://tirto.id/pergolakan-pemikiran-islam-keresahan-keresahan-ahmad-wahib-cGJD. Diakses 17 Mei 2020. 
seperti Yahudi, Nasrani dan Islam. Bahkan, umat Yahudi dihukum oleh Tuhan karena menyembah patung anak sapi dengan tidak mengeluarkan mereka dari Padang Tih selama 40 tahun. ${ }^{233}$ Padahal ketika itu, Musa sedang berbicara dengan Tuhan dan mengambil apa yang terkenal dalam tradisi Yahudi dengan Ten Commademens, Sepuluh Perintah Tuhan. ${ }^{234}$ Dalam Islam, tidak kalah banyaknya hal itu. Dalam al-Qur'an misalnya dikisahkan bagaimana umatumat yang ingkar kepada ajakan rasul Tuhan dihukum dengan berat. Oleh karena itu, agama pada aspek doktrinal sangat melekat dengan masyarakat yang tidak akrab dengan sains.Akhirnya, konstruksi yang dibangun berupa apabila hendak menghindari dari amukan Tuhan, maka harus menuruti apa yang diperintahkan dan menjauhi apa yang dilarang.

Namun hal itu tidak sepenuhnya demikian, karena pada titik tertentu, para agamawan juga cepat sadar akan perkiraan dari para saintis. ${ }^{235}$ Misalnya, respons cepat dari ulama Saudi untuk menutup dua kota suci. ${ }^{236}$ Meniadakan umrah, sempat menutup Masjidil Haram dan Nabawi dalam ibadah salat malam di bulan Ramadan. ${ }^{237}$ Sedangkan untuk ibadah haji, sampai tulisan ini dibuat, belum ada keputusan apakah tahun ini bisa dilangsungkan atau tidak, karena karena menunggu perkembangan terakhir pandemi Covid-19. ${ }^{238}$ Di Indonesia, hal serupa juga dilakukan oleh ormas Islam seperti Muhammadiyah yang menyerukan untuk meniadakan ibadah tarawih di masjid sampai dengan salat Idul Fitri berjamaah. ${ }^{239}$ Namun berbeda dengan varian keagamaan dari kelompok lain yang memilih tetap melaksanakan ibadah seperti biasa, walau dengan himbauan mentaati protokol Covid-19.

Analisis yang dapat diberikan akan hal itu tentu saja berhubungan dengan tipikal dari gerakan agama tersebut. Muhammadiyah misalnya, sebagai organisasi modern, relasi antara anggota dengan pimpinan tidaklah berbentuk patron-

233. Tentang kisah Samiri dan anak sapi, lihat https://republika.co.id/berita/pq1s96313/kisah-samiri-danpatung-anak-sapi. Diakses 17 Mei 2020. Namun ada Analisa lain tentang pengembaraan umat Yahudi di Padang Tih, lihat https://ibtimes.id/hijrah-nabi-musa-dari-mentalitas-inferior-bangsa-israel-hingga-impiantanah-yang-dijanjikan/. Diakses tanggal 17 Mei 2020.

234. Sepuluh Perintah Tuhan itu tentang ajaran yang mengatur hal-hal yang tidak boleh dilakukan oleh umat Yahudi, lihat Budhy Munawar-Rachman (Peny), Karya Lengkap Nurcholish Madjid, (Jakarta: Nurcholish Madjid Society, 2019). hlm. 3679.

235. Dahlan Iskan menangkap hal itu ketika melihat masjid yang dikelola oleh kelompok yang memiliki orientasi skriptularis yang meniadakan salat Jumat, berbanding terbalik dengan kelompok yang memegang tradisi, lihat https://www.disway.id/r/877/berpikir-1000. Diakses 17 Mei 2020.

236. https://www.kompas.com/global/read/2020/04/03/153020170/arab-saudi-tutup-penuh-mekkah-danmadinah-jam-malam-bertambah-jadi-24-jam?page=all. Diakses tanggal 17 Mei 2020.

237. https://republika.co.id/berita/q9jbe9385/tarawih-berjamaah-di-masjidil-haram-dan-nabawi-ditiadakan. Diakses tanggal 17 Mei 2020.

238. https://kemenag.go.id/berita/read/513321/pemerintah-tunggu-kepastian-haji-dari-arab-saudi-hingga-20mei-2020. Diakses tanggal 17 Mei 2020.

239. https://ibtimes.id/hukum-melaksanakan-shalat-idul-fitri-di-rumah/. Diakses tanggal 18 Mei 2018. 
klien yang ketat. Hubungan keduanya lebih diatur oleh aturan organisasi. Jadi, strukturnya lebih terlihat organisatoris. Ini tentu saja berhubungan dengan tipikal organisasi urban yang lebih mengedapankan rasionalitas daripada ketundukan.

Hal itu berbeda dengan organisasi keagamaan tradisional yang relasinya lebih diatur antara santri dengan kyai. ${ }^{240}$ Kyai apabila melepaskan diri dari santri, misal dengan meniadakan ruang publik keagamaan seperti salat, wiridan, tahlilan dan keramaian lainnya, akan kehilangan otoritasnya, karena diambil oleh aturan yang nantinya akan mengikis wibawa kyai. Santri juga demikian, hubungan patron klien dengan kyai kemudian ikut menentukan keberadaannya dalam ruang publik keagamaan. Jadi tidak mungkin, kyai dan santri seluruhnya tunduk kepada peraturan formal, misalnya, yang dibuat oleh negara, bahkan untuk alasan kesehatan sekalipun. Diskursus mengenai otoritas keagamaan dapat dilihat dari tiga unsur penting dalam menopang otoritas keagamaan, yaitu pesantren, NU dan Kyai yang masiha berperen penting dalam kehidupan masyarakat di sana. ${ }^{241}$

Dalam satu video yang beredar luas, salah seorang kyai yang paling dihormati oleh elite politik dan tentu saja oleh para santri, Habib Luthfi, melakukan kontra diskursus dengan narasi resmi negara tentang Covid 19. ${ }^{242}$ Kemudian, juga menyiarkan ramuan yang diyakini secara keagamaan akan dapat melawan Korona. ${ }^{243}$ Apa yang dilakukan oleh Habib Luhtfi adalah cara para kyai mempertahankan otoritasnya di depan santrinya. Dua hal itu, sikap organisasi Muhammadiyah dan kyai NU, menunjukkan bagaimana perspektif berbeda agamawan dan organisasi agama Islam dalam merespons wabah.

\section{Kemampuan Agama Bertahan di Tengah Ancaman Pandemi Covid-19}

Yuvah Noah Harari dalam satu ceramahnya mengatakan bahwa agama adalah sebuah cerita hebat yang ditulis oleh manusia. ${ }^{244}$ Baginya, sebagai seorang

240. Sebagai catatan, secara keorganisasian, PB NU juga seirama dengan PP Muhammadiyah, lihat https:// www.cnnindonesia.com/nasional/20200403193608-20-490193/pbnu-salat-idul-fitri-di-rumah-demicegah-corona. Diakses tanggal 18 Mei 2020.

241. Yanwar Pribadi. (2013). Religious Networks in Madura: Pesantren, Nahdlatul Ulama, and Kiai as the Core of Santri Culture.Al Jamiah.Volume 51. Nomor. 1.

242. https://www.youtube.com/watch?v=MQjO8qMfkpk\&t=225s. Diakses tanggal 22 Mei 2020.

243. https://www.nu.or.id/post/read/117506/virus-corona-merebak--habib-luthfi-bagikan-ijazah-penangkal. Diakses tanggal 18 Mei 2020.

244 .https://www.ted.com/talks/yuval_noah_harari_what_explains_the_rise_of_humans/ transcript?language=id. Diakses tanggal $\overline{1} 8$ Mei 2020. 
sejarawan positivis, hal demikian, mengarang cerita adalah jalan untuk membuat agama dapat bertahan dengan begitu lama. Agama tentu bagi para penganut yang tersebar di seluruh pelosok dunia, bukan seperti yang disampaikan oleh Harari. Agama, dalam filsafat perennial, adalah sesuatu yang primordial. Di dalamnya terkandung dua aspek, eksoterik dan esoterik. Eksoterik adalah aspek yang formal, ritual adalah satunya. Sedangkan esoterik adalah sisi spritualitas.

Bagi penganut agama formal, atau bahkan yang memilih spritualitas, esoterik adalah cara memaknai ketuhanan melalui jalan kemanusiaan. Tentu, agama di sini bukan yang esoterik atau spritualitas, walau sedemikian pentingnya. Namun yang ditunggu adalah agama sebagai institusi sejauh mana akan bertahan di tengah pandemi. Karena dalam setiap kali marabahaya yang diterima oleh umat manusia, selalu saja pertanyaan tentang relevansi agama di mana, bahkan mempertanyakan di mana Tuhan ketika manusia ditimpa kemalangan. Atau, dengan pertanyaan yang lebih filosofis, mengapa orang baik tertimpa kemalangan. Agama, selalu saja berhadapan dengan pertanyaanpertanyaan demikian. Dan, acapkali pertanyaan itu muncul, agama selalu saja dapat bertahan. Walau, ekses dari keberagamaan dengan pola tertentu, membuat pemeluk agama meninggalkan keyakinannya, bahkan lebih memilih ateis.

Merujuk pada Weber, agama dapat bertahan karena menjadi bagian terdalam bagi manusia yang disusun dari norma-norma yang harus ditaati. ${ }^{245}$ Lagi pula, sebagai manusia yang hidup dalam lingkaran institusi, agama selain keluarga, birokrasi dan lingkaran ekonomi, adalah isntitusi yang kuat, bagi masyarakat manapun, terutama bagi masyarakat muslim yang komunal. Bowen dalam risetnya tentang masyarakat muslim di Prancis, mengatakan bahwa yang membuat muslim di negeri itu mengalami kesulitan melakukan perjumpaan dengan kehidupan masyarakat Prancis di sana dikarenakan kuatnya aspek komunal dari Islam, seperti masjid. ${ }^{246}$

Dalam masyarakat Aceh juga demikian. Angka yang terjangkit positif Covid-19 sangat rendah dibanding propinsi lain, dan di saat yang sama, himbauan ulama lebih didengar, untuk tetap mendatangi ruang publik keagamaan. Tentu hal tersebut akan lebih meyakinkan bahwa agama lebih memberikan jawaban, walau sedemikian abstraknya, berbanding dengan sains, dalam menghadapi Covid-19. Agama bertahan ketika jawaban yang bersifat konkret

245. Max weber, Sosiologi Agama..., 407.

246. John R. Bowen, Can Islam Be French: Pluralism and Pragmatism in a Secular State, (Princeton: Princeton University Press, 2009). 
gagal memberikan kepastian. Lalu agama akan dijadikan tempat sandaran untuk memberi ketenangan psikologis. Dalam kasus yang berbeda, itu yang ditemukan oleh peneliti seperti Noorhadi Hasan ketika melihat mengapa gelombang jihad begitu besar ke Ambon. Padahal sejatinya mereka adalah anakanak muda yang gagal bersaing dalam pembangunan. ${ }^{247}$ Agama, dengan segala slogan dan doktrin itu, menurutnya, memberikan ketenangan dan jawaban atas kegagalan dalam kehidupan konkret. Agama, tentu saja tidak memberi jawaban konkret atas pandemi Covid-19. Wacana publik yang berkembang sampai saat ini dan ke depannya, pastilah dikuasai oleh para saintis. Perdebatan pasti melibatkan mereka dan juga pakar sosial lain, baik budaya, politik, ekonomi dan pemerintahan. ${ }^{248}$ Agamawan tidak dilibatkan, dikarenakan agama sedari awal bukanlah ajaran ilmiah, sebagaimana keyakinan para saintis.

Namun, di saat agama diabaikan, agama akan tumbuh dengan otonom untuk memberikan solusi atas kebingungan manusia menghadapi pandemi Covid-19 ini. Agama pastinya tidak akan memberikan jawaban empirik, kecuali dalam beberapa hal seperti menaati protokol kesehatan dan sejenisnya. Agama, yang oleh para agamawan, ulama, kyai, teungku, pastur, pendeta, akan menawarkan gagasan abstrak yang didukung oleh institusi agama yang masih kokoh di dalam masyarakat komunal seperti di Indonesia ini.

Walau demikian, para agamawan juga kini mulai berbicara hal yang lebih konkret namun masih berada dalam tatanan etika, seperti beberapa kajian dari pesantren dan universitas Islam mengenai lingkungan, ${ }^{249}$ bahkan juga sudah mulai bicara secara praksis seperti persoalan sumber daya air. ${ }^{250}$ Melihat trend itu, agama juga akan mencari formula untuk tidak tersingkir dari ruang publik, sebagaimana agama selamat dari sangkaan sebelumnya yang akan tersingkir dengan adanya modernisasi. ${ }^{251}$ Malah yang terjadi kini, agama semakin mendpatkan tempat karena menjadi alasan mereka yang terasing mendapatkan tempat untuk bertahan.

247. Noorhaidi Hasan, Laskar Jihad: Islam, Militansi dan Pencarian Identitas Pasca-Orde Baru, (Jakarta: LP3ES, 2008).

248. Seperti saran dari pakar pemerintahan tentang langkah-langkah strategis apa yang dapat dilakukan oleh pemeritahan Jokowi untuk dapat bertahan dan keluar dari krisis yang disebabkan oleh pandemi Covid-19 ini, lihat Yanuar Nugroho, Visi Sesudah Pandemi, Kompas 15-5-2020.

249. Safrilsyah dan Fitriani, Agama dan Kesadaran Menjaga Lingkungan Hidup, (Banda Aceh: Subtantia, 2014), hlm. 61-62.

250. Muhammadiyah lebih maju dalam melihat persoalan yang berhubungan langsung dengan kebutuhan hidup manusia, lihat http://tarjih.muhammadiyah.or.id/download-seminar-fikih-air.html. Diakses tanggal 18 Mei 2020.

251. Budhy Munawar-Rachman (Peny), Karya Lengkap ..., hlm. 214. 


\section{Penutup}

Tulisan ini hendak menjawab satu pertanyaan utama, tentang bagaimana agama memberikan perspektif mengenai wabah Covid-19, dan bagaimana hal itu dibicarakan dalam konteks hubungan agama dan sains. Mengenai hubungan agama dan sains, selalu saja ada dua varian yang muncul, oposisi binner dan upaya dialog. Dalam sejarah sains di Barat, yang terjadi adalah agama dan sains selalu berada dalam posisi yang bertentangan. Hal yang kemudian berimplikasi terhadap dunia muslim karena interaksi keduanya yang intens di masa lalu. Belakangan ada upaya untuk mendialogkan keduanya dengan beberapa perspektif seperti gerakan islamisasi ilmu pengetahuan, maupun dengan integrasi dan interkoneksi ilmu pengetahuan.

Pada sisi lain, terkait dengan wabah, agama secara doktrinal memberikan perspektif yang khas, bahwa itu bisa jadi hukuman atau cobaan dari Tuhan. Lalu, umat beragama diminta untuk kembali kepada Tuhan dengan ketundukan. Oleh karenanya, ketika Covid-19 mulai mewabah, agamawan juga hadir memberikan kontra narasi dengan sikap negara dan saintis dalam menangani wabah tersebut. Lalu, saling berhadap-hadapan, antara ajaran agama yang abstrak dengan kesimpulan sains yang empirik. Namun demikian, selalu saja ada faksi dalam agama yang menerima kesimpulan sains sebagai landasan pemikiran keagamaan yang dibangunnya. Contoh paling baik tentang itu adalah cara Muhammadiyah dalam merespons Covid-19.

Lalu muncul pertanyaan, ketika wabah semakin menggerus relasi sosial manusia, apakah agama juga akan tergerus dan kehilangan perannya?. Di awal-awal pandemi ini menyebar, terlihat arah itu akan terwujud, terutama ketika ruang publik dan kegiatan keagamaan harus berhenti. Namun, dalam perjalanannya, agama mengambil posisi tersendiri dalam memberi respons terhadap Covid-19, yaitu ketika sains berusaha menemukan jalan keluar dengan penyelidikan yang saintifik, agama hadir untuk memberi rasa aman dari kemungkinan terasingnya manusia akibat derasnya penyebaran Covid-19. Agama pun diyakini akan bertahan, seperti yang sudah terjadi dalam bentangan sejarah panjang umat manusia. 


\section{Daftar Pustaka}

Abu Darda, Integrasi Ilmu dan Agama: Perkembangan Konseptual di Indonesia, Ponorogo: At-Ta'dib, 2015.

Ahmad Baso, Alquran dan Transformasi Sosial dalam Syeh Mahdi dan Singgih Agung, Islam Pribumi:Mendialogkan Agama, Membaca Realitas, Jakarta: Erlangga, 2003.

Ahmad Zainul Hamdi, Agama di Tengah Jaring-jaring Dunia Modern, Surabaya: Religio, 2013.

Ali Machsan Moesa, Nasionalisme Kyai: Konstruksi Sosial Berbasis Agama, Yogyakarta: LKiS, 2007.

M. Amin Abdullah dkk, Islamic Studies dalam Paradigma Integrasi Interkoneksi: Sebuah Antologi,Yogyakarta: Suka Press, 2007.

Amri Marzali, Agama dan KebudayaanBandung: Umbara, 2016

Andik Wahyun Muqoyyidin, Integrasi dan Interkoneksitas Ilmu-Ilmu Agama dan Sains Menuju Pendidikan Tinggi Islam Center of Execellences, Bandung: EduSentris, 2014.

Bambang Sugiharto, Ilmu dan Agama dalam Kurikulum Perguruan Tinggi dalam Zainal Abidin Bagir dkk (Editor), Integrasi Ilmu dan Agama: Interpretasi dan Aksi, Bandung: Mizan, 2005

Budhy Munawar-Rachman dalam Komaruddin Hidayat dan Muhammad Wahyuni Nafis, Agama Masa Depan: Perspektif Filsafat Perennial, (Jakarta: Gramedia, 2003)

Budhy Munawar-Rachman (Peny), Karya Lengkap Nurcholish Madjid, Jakarta: Nurcholish Madjid Society, 2019

Fachruddin M. Mangunjaya, Bertahan di Bumi: Gaya Hidup Menghadapi Perubahan Iklim, Jakarta: Yayasan Obor Indonesia, 2008

Faizin, Integrasi Agama dan Sains dalam Tafsir Ilmi Kementerian Agama RI, Riau: Jurnal Ushuluddin, 2018

Fritz Ridenour, Dapatkah Alkitab Dipercaya? Jakarta: Gunung Mulia, 2000.

Haidar Bagi, Buku Saku Filsafat Islam, Bandung: Mizan, 2005.

Idrus Shahab, Beragama dengan Akal Jernih, Jakarta: Serambi, 2007.

John R. Bowen, Can Islam Be French: Pluralism and Pragmatism in a Secular State, Princeton: Princeton University Press, 2009

Khaled M. Abou Fadl, Atas Nama Tuhan: dari Fiqh Otoriter ke Fiqh Otoritatif, Jakarta: Serambi, 2004

Komaruddin Hidayat, Menafsirkan Kehendak Tuhan, Jakarta: Teraju, 2004

Max Weber, Sosiologi Agama, Yogyakarta: IRCiSoD, 2019 
Moeslim Abdurrahman, Islam sebagai Kritik Sosial, Jakarta: Erlangga, 2003.

Muhammad Taufiq dan Muhammad Yasir, Mengkritisi Konsep Islamisasi Ilmu Ismail Raji Al Faruqi, Yogyakarta: Jurnal Ushuluddin, 2017, hlm. 109-108

Mun'im Sirry, Membendung Militansi Agama: Iman dan Politik dalam Masyarakat Modern, Jakarta: Erlangga, 2003

Muslih, Kritik Ziauddin Sardar terhadap Konsep Islamisasi Ilmu Pengetahuan Ismail Al-Faruqi, Yogyakarta: Tesis UIN Sunan Kalijaga, 2017. Tidak diterbitkan.

Noorhaidi Hasan, Laskar jihad: Islam, Militansi dan Pencarian Identitas Pasca-Orde Baru, Jakarta: LP3ES, 2008

Roby Yansyah dan Rahayu, Globalisasi Lesbian, Gay, Biseksual, dan Transgender (LGBT): Perspektif HAM dan Agama dalam Lingkup Hukum di Indonesia, Semarang: Law Reform, 2018

Safrilsyah dan Fitriani, Agama dan Kesadaran Menjaga Lingkungan Hidup, Banda Aceh: Subtantia, 2014

Said Aqil Siraj, Tasawuf sebagai Kritik Sosial: Mengedankan Islam sebagai Inspirasi, Bukan Aspriasi, Bandung: Mizan, 2006

Septiana Purwaningrum, Elaborasi Ayat-Ayat Sains dalam Al-Quran: Langkah Menuju Integrasi Agama dan sains dalam Pendidikan, Kediri: Inovatif: Jurnal Penelitian Pendidikan, Agama dan Kebudayaan, 2015.

Shafrida Wati, M. Alkaf dan Zahratul Idami, Agama Generasi Milineal: Fenomena Hijrah dan Perubahan Landscape Keislaman di Aceh, Langsa: Penelitian IAIN Langsa, 2019). Tidak diterbitkan.

Siti Yumnah, Diskursus Islamisasi Pengetahuan, Bangil: Pancawahana, 2019

Suranto Aw, Dyna Herlina dan Benni Setiawan, Agama dan Media Diskursus LGBT dalam Opini SKH Republika, Surakarta: Komuniti, 2017.

Syaiful Hamali, Agama dalam Perspektif Sosiologis, Lampung: Al-Adyan, 2017

Syarif Hidayatullah, Agama dan Sains: Sebuah Kajian tentang Relasi dan Metodologi, Yogyakarta: Jurnal Filsafat, 2019.

Tri Ermayani, LGBT dalam Perspektif Islam, Semarang: Humanika, 2017

Tony Ilham Prayogo dan Hadi Fathurizka, Ateisme dalam Perspektif Barat dan Timur, Ponorogo: Alimah, 2019

Yanwar Pribadi. 2013. Religious Networks in Madura: Pesantren, Nahdlatul Ulama, and Kiai as the Core of Santri Culture. Al Jamiah. Volume 51. Nomor. 1

Yanuar Nugroho, Visi Sesudah Pandemi, Kompas 2020-5-15

Yudianto, Fenomena Lesbian, Gay, Biseksual dan Transgender (LGBT) di Indonsia serta Upaya Pencegahannya, Lampung: Nizham, 2016 
Yuvah Noah Harari, Sapiens: A Brief History of Humankind Canada: Signal Book, 2014

Zuhari Misrawi, Al-Quran Kitab Toleransi: Tafsir Tematik Islam Rahmatan Lil 'Alamin, Jakarta: Pustaka Oasis, 2010

\section{Website}

https://covid19.who.int. Diakses tanggal 14 Mei 2020

https://covid19.go.id. Diakses tanggal 14 Mei 2020.

https://saidmuniruddin.com/16/03/2020/bubarnya-agama/ Diakses tanggal 14 Mei 2020

http://tarjih.muhammadiyah.or.id/download-seminar-fikih-air.html. Diakses tanggal 18 Mei 2020.

https://www.disway.id/r/877/berpikir1000-. Diakses 17 Mei 2020.

https://www.kompas.com/global/read/153020170/03/04/2020/arab-sauditutup-penuh-mekkah-dan-madinah-jam-malam-bertambah-jadi-24jam?page=all. Diakses tanggal 17 Mei 2020.

https://republika.co.id/berita/q9jbe9385/tarawih-berjamaah-di-masjidilharam-dan-nabawi-ditiadakan. Diakses tanggal 17 Mei 2020.

https://kemenag.go.id/berita/read/513321/pemerintah-tunggu-kepastian-hajidari-arab-saudi-hingga-20-mei2020-. Diakses tanggal 17 Mei 2020

https://ibtimes.id/hukum-melaksanakan-shalat-idul-fitri-di-rumah/. Diakses tanggal 18 Mei 2018.

https://www.cnnindonesia.com/nasional/490193-20-20200403193608/pbnusalat-idul-fitri-di-rumah-demi-cegah-corona. Diakses tanggal 18 Mei 2020.

https://bagbudig.com/pandemi-corona-dan-suwa-empire/. Diakses 17 Mei 2020.

https://aceh.tribunnews.com/23/03/2020/virus-dan-obat-penangkalnyadalam-perspektif-masyarakat-aceh. Diakses tanggal 17 Mei 2020

https://www.tagar.id/daya-tahan-tubuh-orang-aceh-kuat-di-tengah-corona. Diakses tanggal 17 Mei 2020.

https://aceh.tribunnews.com/02/04/2020/memerahkan-jari-dengan-dauninai-dipercaya-bisa-cegah-corona-benarkah. Diaskes 17 Mei 2020.

https://aceh.tribunnews.com/21/04/2020/mpu-aceh-bolehkan-warga-shalattarawih-di-masjid-asal-terpenuhi-syarat-ini. Diakses tanggal 17 Mei 2020.

https://kemenag.go.id/berita/read/513202/dirjen-bimas-islam--ramadan-dirumah-tak-mengurangi-kualitas-ibadah. Diakses tanggal 17 Mei 2020.

https://www.youtube.com/watch?v=MQjO8qMfkpk\&t=225s. Diakses tanggal 22 Mei 2020. 
https://www.nu.or.id/post/read/117506/virus-corona-merebak--habib-luthfibagikan-ijazah-penangkal. Diakses tanggal 18 Mei 2020.

https://www.ted.com/talks/yuval_noah_harari_what_explains_the_rise_of_ humans/transcript?language=id. Diakses tanggal 18 Mei 2020

https://kemenag.go.id/berita/read/513332/menag--masih-pandemi--salat-iddi-rumah-dengan-keluarga-inti. Diakses tanggal 17 Mei 2020.

https://mui.or.id/berita/27848/mui-keluarkan-tausiyah-ramadhan-1441-h-ditengah-wabah-covid19-/. Diakses tanggal 22 Mei 2020

https://tirto.id/pergolakan-pemikiran-islam-keresahan-keresahan-ahmadwahib-cGJD. Diakses 17 Mei 2020.

https://republika.co.id/berita/pq1s96313/kisah-samiri-dan-patung-anak-sapi. Diakses 17 Mei 2020.

https://ibtimes.id/hijrah-nabi-musa-dari-mentalitas-inferior-bangsa-israelhingga-impian-tanah-yang-dijanjikan/. Diakses tanggal 17 Mei 2020.

https://insists.id/pengantar-pemikiran-syed-muhammad-naquib-al-attas/. Diakses 202017.

https://secularhumanism.org/01/2020/men-without-god-the-rise-of-atheismin-saudi-arabia/. Diakses tanggal 17 Mei 2020. 